State before they could marry. Application for such permission required payment of a fee and permission would only be granted (in the absence of especially compassionate features) if the applicant had been granted the right to remain in the United Kingdom for at least six months and there were at least three months of that period remaining at the time of application. The House observed that the right to marry under Article 12 was a 'strong' right. National authorities were entitled to impose reasonable conditions on the right of a third-country national to marry for the purposes of ascertaining whether the marriage in question was a marriage of convenience and therefore not a genuine marriage warranting the protection of Article 12. Insofar as the scheme restricted the right to marry, it could only be justified to the extent that it operated to prevent marriages of convenience. In fact, the conditions imposed by the scheme had no relevance to whether the marriage was genuine or not. Rather, the scheme operated as a blanket prohibition (subject to the discretion in relation to the exception for especially compassionate features) on all marriages, whether genuine or not. As such, the scheme operated in such a way as to be a disproportionate interference with the right marry. The appeal was dismissed. [RA]

doi:10.1017/So956618X09001859

\title{
Gallagher v Church of Jesus Christ of Latter-day Saints
}

House of Lords: Lords Hoffman, Hope, Scott, Carswell and Mance, July 2008

Rating - public worship - freedom of religion - Mormon temple

The Church of Jesus Christ of Latter-day Saints (LDS) appealed against the decision that buildings (including a temple) on one of its sites did not qualify for the non-domestic rating exemption under Schedule 5 of the Local Government Finance Act 1988. The principle issues in the appeal were:

i. Whether the temple was a 'place of public religious worship' for the purposes of the 1988 Act (and therefore entitled to the exemption); and

ii. Whether the exclusion of the temple from such relief amounted to indirect discrimination in breach of Articles 9 and 14 of the European Convention on Human Rights.

The House dismissed the appeal, finding that the first issue had already been determined against the LDS by its earlier decision in Church of Jesus Christ of Latter-day Saints v Henning [1964] AC 420. There was no reason to suggest that Parliament intended the wording of the 1988 Act to hold a different meaning from the terms of its statutory predecessor under consideration in Henning. 
The temple was not a place of public religious worship as it was not open to the public but only to those members of the LDS who had obtained the relevant 'recommend'. Further, the majority of the House held that the exclusion of the temple from such relief did not amount to indirect discrimination as alleged. The rating liability of the temple would not prevent members of the LDS from manifesting their religion. The LDS was not taxed on account of its religion; rather its doctrine and polity prevented it from providing the public benefit necessary to secure a tax advantage. Lord Scott of Foscote expressed doubt about this conclusion but the House unanimously held that, if there was any indirect discrimination, that it was justifiable as being within the margin of appreciation available to individual signatory states under the Convention. [RA]

For a critique of this decision, see $R$ Sandberg, 'Underrating human rights: Gallagher v Church of Jesus Christ of Latter-day Saints' on pages 75-80 of this issue.

doi:10.1017/So956618Xo9001860

\section{Singh v Aberdare Girls' High School}

Administrative Court: Silber J, July 2008

Sikh bangle - indirect discrimination - race and religion

Singh, a Sikh schoolgirl, applied for judicial review of her school's refusal to allow her to wear a religious steel bangle (the Kara) at school on the basis that it contravened the school's uniform policy with respect to the wearing of jewellery. Singh's request for an exemption from the uniform policy in this regard was refused. Singh had been segregated from other pupils and ultimately told that she would only be permitted to attend the school if she did not wear the Kara. She claimed that these actions amounted to indirect discrimination on grounds of race under the Race Relations Act 1976, and on grounds of religion under the Equality Act 2006. The Court held that the school's refusal to depart from its uniform policy and allow Singh to wear the Kara amounted to indirect discrimination on grounds of race and on grounds of religion. It was held that Singh had suffered a detriment or disadvantage in that she had been forbidden from wearing an item that she genuinely believed, for reasonable grounds, was a matter of exceptional importance for her racial identity or religious belief. The wearing of the Kara could be shown objectively to be of exceptional importance to her religion or race, even though the wearing of that item was not an actual requirement of her religion. The Court held that the school had failed to justify the discrimination. The cases of $R$ (on the application of X) $v Y$ School $^{1}$ and $R$ 